\title{
Research \\ Relating Biodiversity and Landscape Spatial Patterning to Land Ownership Regimes in Northeastern Mexico
}

\author{
Miguel Alfonso Ortega-Huerta ${ }^{1}$ and Karla Kae $\mathrm{Kral}^{2}$
}

\begin{abstract}
Land legislation has changed dramatically in Mexico during recent years, putting greater emphasis on the integration of free market policies into local production methods. In a country like Mexico, replacement of traditional methods of production may result in the loss of practices that protect the natural environment. With the objective of providing baseline information for future conservation and/or land management programs, I evaluated how landscape patterning and the richness of bird and mammal species varied among current land ownership sizes and types, applying a stratified scheme that controlled for potential variation among different physiographic regions. I characterized landscape spatial patterning using the aggregation index, Shannon's Diversity Index, and the Modified Simpson's Evenness index, and I used the GARP modeling approach to estimate species richness within each land ownership regime. Particular attention was paid to variation among community-based vs. individually based ownership types. A notable finding with regard to parcel size is that there is a general pattern in which medium-tolarge parcels contained greater percentages of natural vegetation; this relationship is less consistent for the largest parcels. Regarding land ownership types, community-based lands generally presented higher estimates of habitat conservation, i.e., a higher percentage of natural vegetation, higher aggregation, and more even distribution of land cover types, and a greater richness of bird and mammal species. These results suggest that attention should be paid to evaluating the importance of different types of land ownership in determining spatial patterns of biodiversity. Furthermore, these initial assessments, of how landscape structure and species richness varies across land ownership regimes, serve as reference points for future evaluations of change in landscape and biodiversity spatial patterns in Mexico.
\end{abstract}

Key Words: community-based ownership; land ownership regime; landscape patterning; private-based ownership; species richness.

\section{INTRODUCTION}

Private, communal, private-communal-government complex, and public or government owned lands are different types of land ownership that are legally recognized in Mexico (Ley Agraria 1992), and which represent social and economic relations with particular legal forms (Bartra 1993). Socioeconomic analyses have revealed the role that the various land tenure systems have on the decision-making process taken by landholders (Wunderlich and Chryst 1958, Gilbert and Harris 1984), and particularly related to their environmental impacts (e.g., Hardin 1968, Ostrom 1992, Rose 2002).

The variety of social, economic, and cultural conditions associated with different types of land tenure may determine particular strategies by which landholders manage natural resources. For example, different extensive vs. intensive cattle-raising systems generate different types of impacts on natural environments (Toledo 1987). Where systems of common property controlled by local users prevail, particular patterns of land use can be anticipated (Young 2000). Numerous human ecologists, environmental sociologists, and others have brought land ownership to the forefront of rural research (Geisler and Salamon 1993). Geographers, anthropologists, biologists, and other research scientists have been looking at the conservation value of traditional strategies since beginning of the 1980s (Klee 1996).

Economic and ecological strategies take place when campesinos, i.e., traditional farmers, use natural resources as irreplaceable means for subsistence (Toledo 1992). Klee (1996) illustrates today's relevance for studying traditional forms of natural 
resource use by listing over 30 conservation principles practiced by many of the world's traditional societies. Examples of traditional agriculture that have achieved long-term sustainable management of natural resources include: (1) multiple cropping and interactions with natural vegetation (Denevan et al. 1984, Brush 1986, Wilken 1989, Gliessman 1992); (2) applying terracing and irrigation techniques, raised fields, and the use of organic fertilizers (Denevan 1980); and (3) producing a varied diet and using a diversity of locally available resources (Altieri 1993).

A few studies have investigated the role of land ownership types in impacting natural environments. Using optimization algorithms, Beaumont and Walker (1996) identified access to farming technology and off-farm employment opportunities as key factors in determining how different property regimes would affect the environment. In forested environments, Crow et al. (1999) studied the interaction between the physical environment and two land ownership types, i.e., federal and private, creating spatial heterogeneity in northern Wisconsin. Lovett-Doust and Kuntz (2001) found that most measures of biotic diversity differed significantly among private, public, and mixed land ownership. For globally rare biota, Lovett-Doust et al. (2003) found that area had greater effects on species richness than did ownership types. Contradicting Hardin's (1968) parable "The Tragedy of the Commons," Feeny et al. (1990) documented evidence indicating that private, state, and communal property are all potentially viable resource management options. Case studies from Africa (e.g., McCabe 1990, Matzke and Nabane 1996) have also demonstrated that communal ownership of land does not necessarily lead to environmental degradation.

Although many types of land ownership are legal in Mexico, e.g., federal, national, private, Ejido, etc., a key distinction is community-type ownership vs. individual private ownership (Warman 1984, Ley Agraria 1992, Brunt 1992, Bartra 1993, De Gortari 2002). Because about $80 \%$ of Mexico's forested areas are held under community-type ownership schemes (Merino 2004) and these types are often associated with traditional management strategies, the country is considered a unique case for studying the social and ecological benefits of delivering control of forests to local communities (Barton et al. 2003). However, the structural conditions of Mexico's collectively owned land are changing because of relatively recent land reforms. In 1992 the Mexican government made a constitutional amendment ending the Ejido's special legal status and permitting the sale of collectively controlled lands (Cornelius and Myhre 1998, Snyder 1998). Ejido represents an amalgamation of various types of land ownership, e.g., state, corporative, communal, and private (Bartra 1993).

The objective of this study is to identify potential differences in spatial patterns of landscape features and biodiversity that are associated with different types and sizes of land ownership in northeastern Mexico (Fig. 1). Particularly, I address two general research questions for the region: (1) Are there significant differences in landscape patterning and the levels of biodiversity, i.e., species richness of birds and mammals, among the different types and sizes of land ownership? and (2) How are such potential differences revealed by grouping community-based vs. private land ownership types? Evaluating the role of land tenure systems in conserving biodiversity is particularly relevant given: (1) the necessity for integrating human local populations to conservation strategies; and (2) the land legislation changes experienced in Mexico during recent years (1992 Agrarian Reform) and their potential environmental effects (Toledo 1996, Barton-Bray 1996, Wexler and Barton 1996, Whiteford and Bernal 1996, DeWalt 1998, Whiteford et al. 1998, Zabin 1998). For answering such questions, I apply a niche modeling approach to propose models of current distributions for bird and mammal species, included those considered threatened, endangered, or with restricted distribution, and I quantitatively evaluate the spatial patterns of remaining natural habitats. The goal of this work is to contribute in evaluating the role of different types of land ownership for conserving regional patterns of biodiversity.

\section{METHODS}

Regional spatial patterns of landscapes and biodiversity were analyzed in relation to different land ownership regimes, i.e., size and land tenure type, in northeastern Mexico (Fig. 1). Land ownership data corresponding to 1984-1989 were obtained from the Registro Nacional Agrario (RAN, National Agrarian Registry) through its Catastro Rural Histörico (Rural Historic Cadastral) office. 
Fig. 1. Study area in northeastern Mexico, showing six physiographic provinces or subregions. The three subregions used for analyzing land ownership types consisted of (1) sierras (Gran Sierra Plegada, KARST Huasteco, and Sierra de Tamaulipas, (2) Costa del Golfo (Llanuras y Lomeríos de la Costa del Golfo Norte, Llanura Costera Tamaulipeca, and Llanuras y Lomerios de Veracruz,) and (3) Llanuras OccidentaleS (Sierras y Llanuras Occidentales, Sierras y Llanuras del Norte de Guanajuato, and Llanuras y Sierras de Querétaro e Hidalgo).

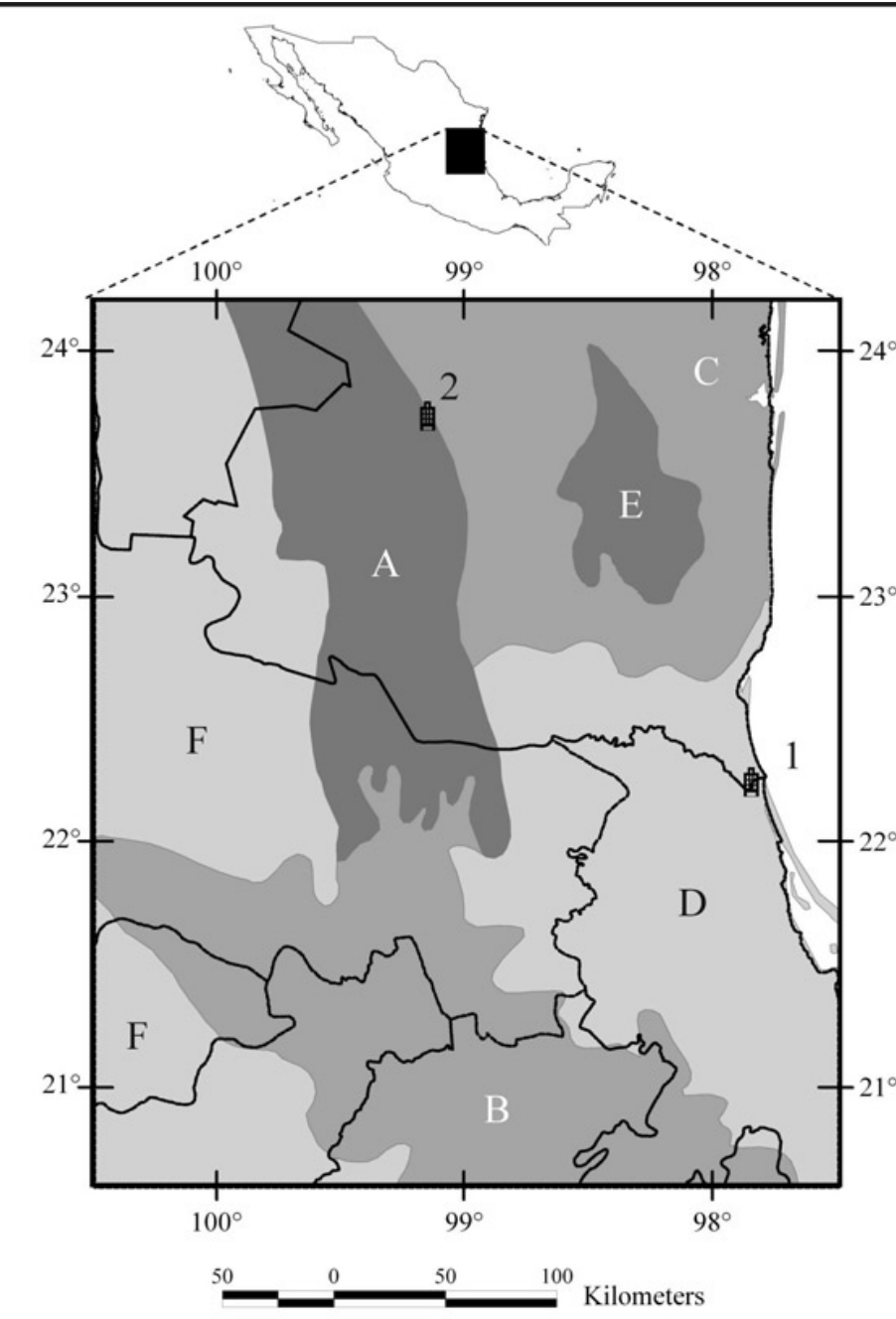

Physiographic Provinces

$\mathbf{A}=$ Gran Sierra Plegada (GSP)

Main Cities

$\mathbf{B}=$ Karst Huasteco $(\mathrm{KH})$

1. Tampico

C $=$ Llanura Costera/ Lomeríos Costa Golfo Norte

2. Cd. Victoria (LL-TAM)

D = Llanuras y Lomeríos Veracruz (LL-VER

$\mathbf{E}=$ Sierra de Tamaulipas (S-TAM)

State boundaries

$\mathbf{F}=$ Sierras y Llanuras (LL-OCC) 
These data were originally in Auto-Cad (DFX) vector format, projected in UTM coordinates. They were read using Arc/INFO Atlas-Map 8.1 (ESRI) and then converted to Arc/INFO shape format. A series of queries was performed to classify land use parcels across the landscape of northeastern Mexico into 15 parcel-size intervals (Table 1) and 8 land ownership types (LOTs, Table 2). Data were transformed to ArcGrid format matching the spatial resolution of the rasterized land use/land cover data $(100 \times 100 \mathrm{~m}$ pixel size $)$.

For comparison purposes, the Colonia regime (COL) was categorized as a private ownership form because of its historical origins. Since the 1910 revolution, federal and state governments significantly promoted land colonization for establishing private holdings called colonias agröcolas y ganaderas, i.e., new settlements for agriculture and cattle raising, in opposition to Ejido or collective land ownership (SRA 2002). However, the functioning of such colonias is regulated by the Mexican government in similar fashion as Ejidos (SRA 1993), including a collective organization resembling the Ejido. For the purposes of this study, COL is considered a mixed form of private LOT, in a similar way that Ejido is a mixed form of community-based LOT.

Because landscape structure and richness are likely to vary among contrasting physiographic regions, reflecting the region's remarkable environmental heterogeneity, e.g., topography and climate, I stratified the types and sizes of parcels according to physiographic provinces or subregions within the whole study region. Parcel size was analyzed based on location within six subregions, which correspond to distinct physiographic provinces (Fig. 1): (1) Gran Sierra Plegada (GSP, Great Folded Sierra), (2) Karst Huasteco (KH, Huastec Karst), (3) Lomeröos de la Costa Golfo Norte/Llanura Costera Tamaulipeca (LL-TAM, Hills of the Northern Gulf/ Tamaulipan Coastal Plain), (4) Llanuras $y$ Lomeröos in Veracruz (LL-VER, Plains and Hills of Veracruz), (5) Sierra de Tamaulipas (S-TAM, Tamaulipan Sierra), (6) Sierras y Llanuras Occidentales (LL-OCC, Western Sierras and Plains).

On the other hand, given their uneven representation across the region, the eight LOTs were stratified only within three subregions (see Fig. 1): (1) sierras (Gran Sierra Plegada, KARST Huasteco, and Sierra de Tamaulipas), (2) Costa del Golfo (Llanuras y
Lomeröos de la Costa del Golfo Norte, Llanura Costera Tamaulipeca, and Llanuras y Lomerios de Veracruz), and (3) Lanuras Occidentales (Sierras y Llanuras Occidentales, Sierras y Llanuras del Norte de Guanajuato, and Llanuras y Sierras de Querötaro e Hidalgo).

Calculations of landscape spatial patterning were obtained using the 2000 Inventario Nacional Forestal (INF, 2000 National Forestry Inventory), a high resolution $(100 \times 100 \mathrm{~m}$ pixel size, after transformation into ArcGrid format) updated land use/land cover (LULC) map (SEMARNAT 2001). Before using the map, an accuracy assessment was carried out to evaluate its suitability for this study. The original INF map was reclassified from 55 LULC types to 21 classes corresponding to the vegetation formation level (see Table 3 ). Using a Garmin II GPS unit and 1:50,000 topographic maps, and supported by botanists from the region (Instituto de Ecologöa y Alimentos-Universidad Autönoma de Tamaulipas), 1565 sites were surveyed to obtain samples for LULC types representative of different areas across the region. Overall accuracy obtained was $74.5 \%$ for the reclassified 21-class INF.

Landscape metrics were calculated with Fragstats spatial pattern analysis program for quantifying landscape structure, Version 3.1 (McGarigal 2002). The vegetation map (INF) consisted of 21 LULC types, rasterized at a resolution of $100 \mathrm{~m}$. Because of the relevance of vegetation formations for revealing regional heterogeneity, I decided not to further generalize the vegetation map, e.g., natural vegetation vs. human-transformed environments. Patches were spatially defined based on the 4-cell rule, i.e., a patch was defined if two pixels were connected by at least one of their sides.

Considering the high correlation among landscape metrics, e.g., contagion, aggregation, diversity, evenness, split, cohesion, interspersion and juxtaposition, I decided to use only the Aggregation Index (AI) to summarize the spatial patterns of landscapes. AI, complemented with the proportion of natural vegetation, the Shannon's Diversity Index (SHDI), and the Modified Simpson's Evenness Index (MSIEI) enabled me to compare landscape configurations associated with different parcel sizes and types of land ownership. The calculations of these landscape metrics were made, based on the remaining natural vegetation, to emphasize its actual spatial configuration. 
Table 1. Classification of land ownership data by parcel size.

\begin{tabular}{lc}
\hline \hline Interval Code & Size Interval (ha) \\
\hline a & $0-25$ \\
$\mathrm{~b}$ & $26-50$ \\
$\mathrm{c}$ & $51-100$ \\
$\mathrm{~d}$ & $101-150$ \\
$\mathrm{e}$ & $151-250$ \\
$\mathrm{f}$ & $251-500$ \\
$\mathrm{~g}$ & $501-1000$ \\
$\mathrm{~h}$ & $1001-1500$ \\
$\mathrm{i}$ & $1501-2000$ \\
$\mathrm{j}$ & $2001-3000$ \\
$\mathrm{k}$ & $3001-4000$ \\
$\mathrm{l}$ & $4001-5000$ \\
$\mathrm{~m}$ & $5001-7500$ \\
$\mathrm{n}$ & $7501-10,000$ \\
$\mathrm{o}$ & $>10,000$ \\
\hline
\end{tabular}

AI (Eq. 1) is defined as the number of like adjacencies involving the corresponding class, divided by the maximum possible number of like adjacencies involving the corresponding class, which is achieved when the class is maximally clumped into a single, compact patch. AI is 0 when the focal patch type is maximally disaggregated. AI increases as the focal patch type is increasingly aggregated and equals 100 when the patch type is maximally aggregated into a single, compact patch (McGarigal 2002). The AI used for characterizing the landscape spatial configuration, associated to the different sizes and types of land ownership regimes, was obtained from averaging the AI corresponding to each type of original vegetation. SHDI (Eq. 2) equals 0 when there is a single patch, i.e., no diversity, and increases as the number of different patch types increases and/or the proportional distribution of area among patch types becomes more equitable (McGarigal 2002). The modified Simpson's Evenness Index (MSIEI) (Eq. 3 ) measures the evenness in the distribution of areas among different types of patches. MSIEI is 0 when the distribution of areas among the different patch types become increasingly uneven, and MSIDI is 1 when distribution of areas among patch types is perfectly even (McGarigal 2002). The percentage of natural vegetation associated to each parcel-size class and ownership type, was obtained from the area calculations generated by the Fragstats' class analysis. 
Table 2. Land ownership types provided by the Resgistro Agrario Nacional.

\begin{tabular}{lccc}
\hline \hline Land Ownership Type & Abbreviation & English Translation & Ownership Form \\
\hline Ejido & EJ & Ejido & Collective/individual \\
Nuevo Centro de Población & NCP & New population & Collective/individual \\
(NCP) & COM & Communal & Community \\
Comunidad & PEQ & Small property & Private \\
Pequeña Propiedad & PP & Private property & Private \\
Propiedad Privada & COL & New neighborhood & Private \\
Colonia & ZF & Federal zones & Government \\
Zona Federal & TN & Nation lands & Government \\
Terrenos Nacionales & & Litigation lands & \\
Zonas en Conflicto & Urban areas & \\
Zonas Urbanas & & Abandoned lands & \\
Terrenos Baldíos & Surplus lands & Private \\
Excedencia & & Multiple owners & \\
Fraccionamiento & Unidentified & Government \\
No Identificado & National park & \\
Parque Nacional & & & \\
& & &
\end{tabular}

Spatial patterns of biodiversity were modeled using the Genetic Algorithm for Rule-set Prediction (GARP) system (Stockwell and Peters 1999) to model ecological niches of species and geographic distributions. The GARP system was used because of its proven ability to generate predictions of species distributions in Mexico, obtained from species collection sites, even with a small sample size, and a set of environmental variables (e.g., Stockwell and Peterson, 2002a, 2002b). Natural history museum data consisting of locality records of species' occurrences and 15 selected environmental attributes, i.e., elevation, aspect, slope, climate type, ecoregion, physiography, vegetation's structural physionomy, humidity regime, mean annual temperature, mean annual precipitation, maximum daily temperature, minimum daily temperature, maximum annual temperature, minimum annual temperature, and potential vegetation, provided by the National Commission for Study and Conservation of Biodiversity (CONABIO 2003), were input into GARP for modeling species' ecological niche (Peterson 2001). Selection of the best subset of models for each of 285 bird and 114 mammal species followed Anderson et al. (2003). Detailed procedures for generating GARP predictions of species' potential geographic distributions can be found in OrtegaHuerta and Peterson (2004).

Current geographic distributions of species were then generated by intersecting potential distributions 
Table 3. Inventario Nacional Forestal 2000 (SEMARNAP 2000). Land use/land cover classes (LULC) used for analyzing landscape patterning associated to different land ownership regimes in northeastern Mexico.

Land use/land cover

1- Agriculture

2- Urban areas

3- Grassland

4- Oak forest

5- Pine forest

6- Pine-oak forest

7- Cloud forest

8- Juniper forest

9- Chaparral

10- Scrub land

11- Tropical dry forest

12- Tropical semi-evergreen forest

13- Tropical evergreen forest

14- Palm forest

15- Coastal dune vegetation

16- Riparian forest

17- Halophytic vegetation

18- Water bodies

19- Wetlands

20- Mangrove

21- Bare soil 
for each species with the land cover types on the map considered suitable for the occurrence of a particular species. Species-habitat associations were documented as described in Ortega-Huerta and Peterson (2004).

For obtaining the spatial distribution of bird and mammal richness, current species distributions, i.e., binary models were then summed. Richness data were then extracted for the eight LOTs in the three subregions, i.e., Costa del Golfo, Sierras, and Llanuras Occidentales. Percentages of the area occupied by each richness interval, in relation to the total area of each land ownership type, were plotted in histograms. Finally, groups of species considered endangered, threatened, or with restricted distribution (ETRD) were also used as species indicative of biodiversity patterns. Current distributions corresponding to ETRD bird and mammal species were overlaid on the land ownership type data to obtain percentages of the distributional area of each species in each land ownership regime. The use of ETRD species as biodiversity indicators was supported by: (1) relatively high correlations between the current richness patterns of the entire set of species and those corresponding to ETRD species $\left(R^{2}=0.88\right.$ for birds, and $R^{2}=0.54$ for mammals); and (2) the spatial coincidence of areas with highest current species richness (107-120 birds, and 34-45 mammals) and areas with the highest current ERTD species richness.

\section{RESULTS}

Land ownership data provided by the National Agrarian Registry (RAN) contained 15 types of land tenure shown in Table 1. However, seven of these types were eliminated from this analysis because of their small area (sum $<1.0 \%)$ or lack of analytical role, e.g., land ownership was undefined because of litigation, abandonment, or multiple-owner lands.

\section{Landscape patterns and land ownership types}

The Ejido (EJ) and Propiedad Privada (PP, Private property) types occupied basically the same proportion (39\% each) of the total land ownership mapped, followed by Zona Federal (ZF, Federal Zone) $(5.3 \%)$, Pequeña Propiedad (PEQ, Small Property) (4.3\%), Nuevo Centro de Población (NCP, New Centers of Population) (3.8\%),
Comunal (COM, Communal) (3.8\%), Colonia (COL, Colony) (2.8\%), and Terrenos Nacionales (TN, National Lands) (1.2\%). Figure 2 combines the AI-NV and PNV results to show more specifically the differences in landscape patterning associated with each LOT within each subregion. These results supported by the diversity of original vegetation index (SHDI) and the modified Simpson evenness index (MSIEI) provide the characterization of the landscape patterning among LOTs within each subregion:

Costa del Golfo (Fig. 2a): In this region, TN, and two community-based types (NCP and COM) had highest AI-NV values (92-95\%), whereas COL, PEQ, and ZF had the lowest (73-78\%). TN lands had the highest proportion of remaining original vegetation and PEQ had the lowest (11\%). EJ and PP lands had the highest diversity of original vegetation (SHDI: 1.52 and 1.47, respectively), whereas COL and COM showed the lowest values (0.01 and 0.27, respectively, see Fig. 3). Differences among LOTs are also revealed by the modified Simpson evenness index (MSIEI); COM lands had the highest evenness in LULC (0.6), whereas low MSIEI values corresponded to PP (0.34), EJ (0.40), and ZF (0.40).

Llanuras Occidentales (Fig. 2b):TN and all community-based lands (COM, EJ, COL, and $\mathrm{NCP}$; ) had the highest AI-NV values (>90\%), whereas the lowest was shown by ZF (78\%). TN lands had the highest PNV value $(96 \%)$, whereas private-owned PP and PEQ had lower PNV values (57 and $66 \%$, respectively) than the communitybased COL and EJ (70 and $77 \%$, respectively). COM lands had the highest diversity of original vegetation $(\mathrm{SHDI}=1.56)$, followed by $\mathrm{PP}, \mathrm{ZF}$, and TN ( 1.0) (Fig. 3). Like the Costa del Golfo region, in the Llanuras Occidentales the COM lands clearly showed the highest evenness (0.80), which revealed the relatively even distribution of areas corresponding to several LULC. The two privateowned LOTs, PP and PEQ, along with ZF, had MSIEI values higher $(0.48-0.52)$ than the two community-based LOTs $(\mathrm{COL}=0.37$ and $\mathrm{EJ}=0.32)$.

Sierras (Fig. 2c): Similarly to the previous subregion, two community-based LOTs, NCP, and COM, showed the highest AI-NV values (95 and 93\%, respectively), along with PEQ and TN $(\sim 91 \%)$. ZF, COL, and PP lands showed the lowest aggregation of natural vegetation (86-87\%). After TN (96\%), NCP also had highest PNV value (76\%). 
Fig. 2. Aggregation Index (AI, empty bars) and percentage of natural vegetation (PNV, gray bars) by land ownership type, in three subregions: (a) Costa del Golfo, (b) Llanuras, and (c) Sierras. Land ownership types include: $\mathrm{COL}=$ colonia, A settlement for agriculture/cattle-raising), $\mathrm{COM}=$ communal, $\mathrm{EJ}=$ Ejido, $\mathrm{NCP}=$ new population settlement (new Ejido), $\mathrm{PEQ}=$ small private property, $\mathrm{PP}=$ private property, $\mathrm{TN}=$ Nation lands, and $\mathrm{ZF}=$ federal lands.

(a)

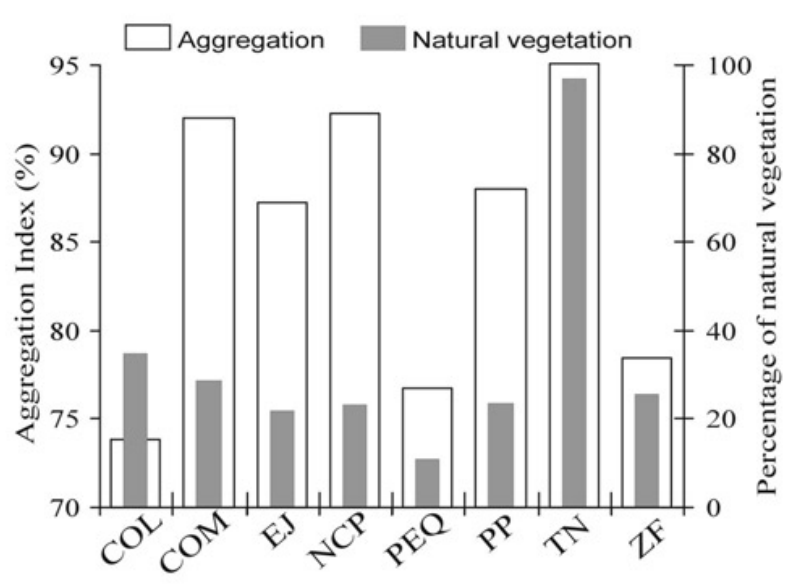

(b)

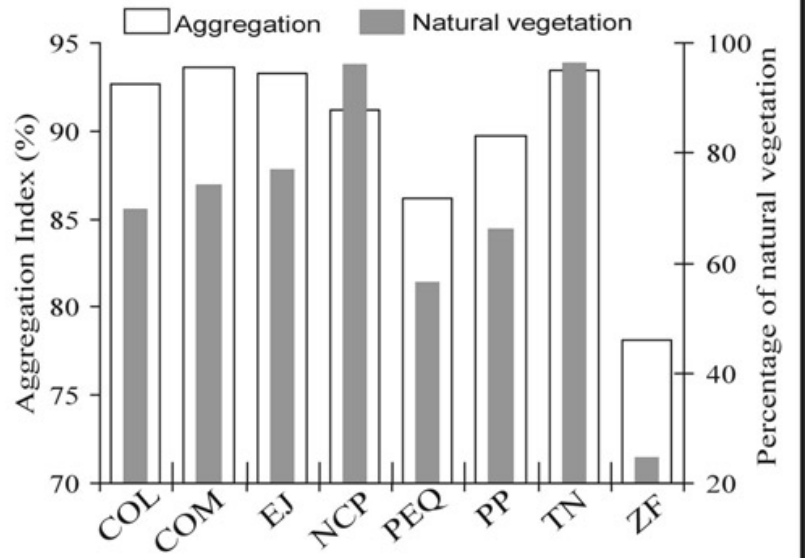

(c)

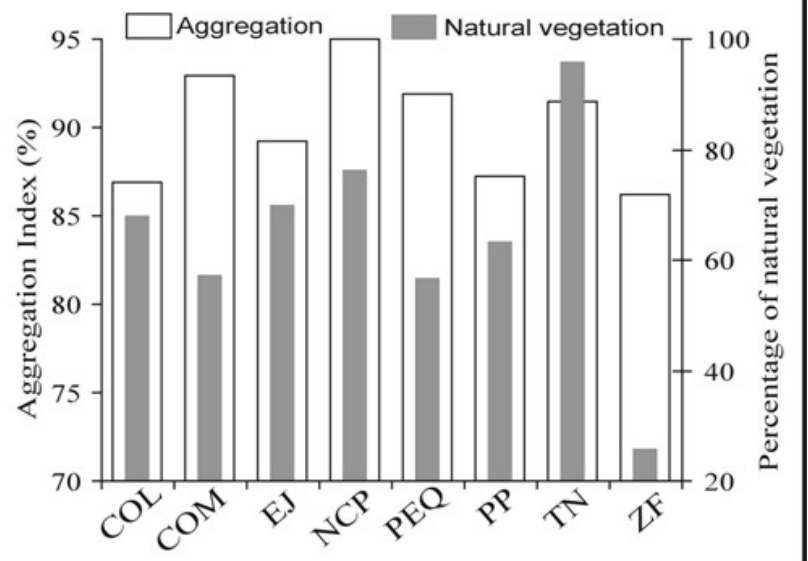


Fig. 3. Shannon's Diversity Index of remaining natural vegetation by land ownership types at three subregions: Costa del Golfo, and Llanuras y Sierras.

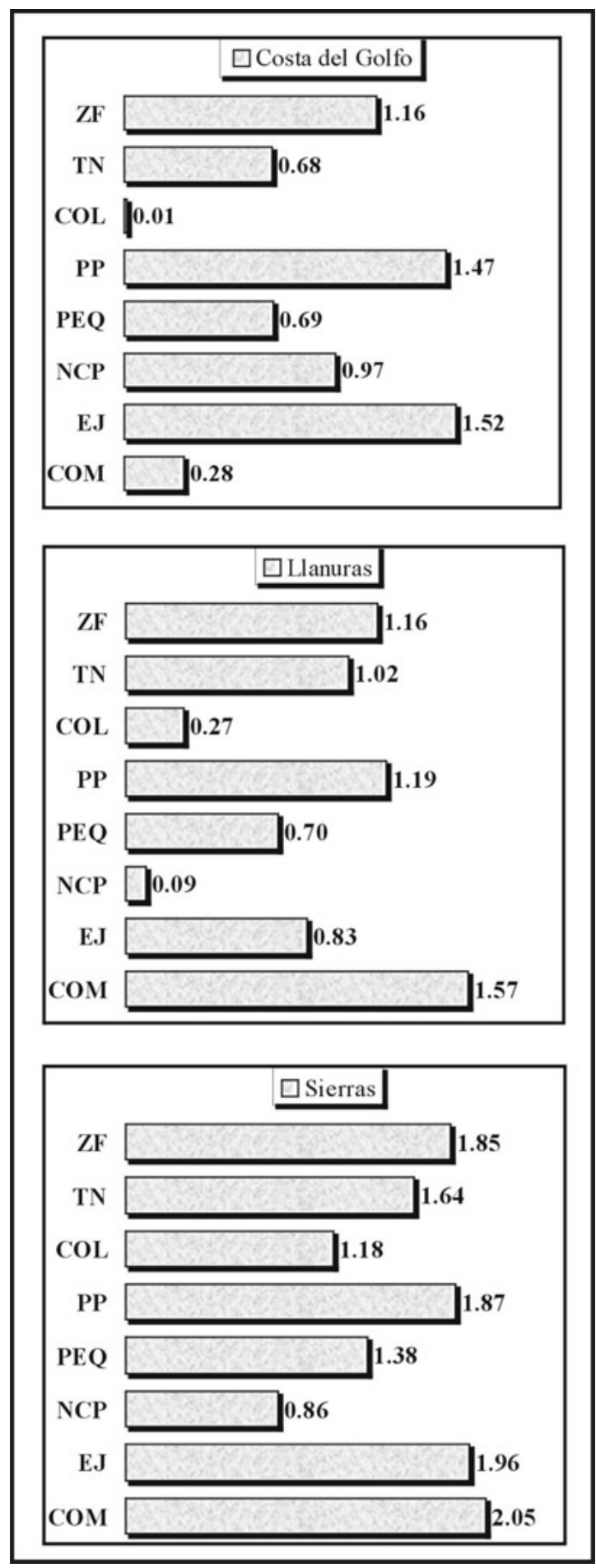


LOTs in this region showed uniformly highest diversity of original vegetation (see Fig. 3) as compared to the Costa del Golfo and Llanuras Occidentales subregions. The highest diversity was shown by COM (2.0), followed by EJ (1.9), PP (1.8), and ZF (1.8) (Fig. 3). The distribution of LULC areas within each LOT showed a pattern in which the two private-owned PP and PEQ along with the two community-based COM and EJ had similarly highest evenness of LULC (0.66-0.68).

Figure 4 summarizes the differences in landscape patterning corresponding to community based vs. private. Based on the percentage of natural vegetation still remaining (PNV); (1) In the Costa del Golfo (community based $=25 \%$ vs. private $=$ $23 \%$ ) the prevalent type of private ownership (PP) had similar PNV that Ejido, i.e., EJ-the prevalent community-based ownership, and NCP, but other private types such as PEQ, showed a higher dominance of introduced grassland; (2) In the Llanuras Occidentales (community-based $=83 \%$ vs. private $=64 \%$ ), the three community-based LOTs (NCP, EJ, and COM) along with TN had both the highest PNV and the most diverse natural vegetation; and (3) In the Sierras region, the community-based land had a PNV $=68 \%$, whereas the private type was $63 \%$. Figure 4 also shows that aggregation was uniformly higher for the community-based lands vs. private lands; 92 vs. 88 at Costa del Golfo, 91 vs. 86 at Llanuras, and 89 vs. 87 at the Sierras.

\section{Landscape patterning and land ownership types}

The complexity of the region's land ownership mosaic is revealed by the 73,822 polygons, i.e., parcels that make up the land tenure configuration included in this study. Figure 5 shows the patterns of changes in AI and PNV values as a function of parcel size. Detailed AI and PNV results associated to parcel size are provided for each of the six physiographic provinces.

Llanuras y Lomerios in Tamaulipas (LL-TAM) and Llanuras y Lomerios in Veracruz (LL-VER) had the lowest percent of natural vegetation (PNV) across all parcel size intervals (37.6 \pm 8.4 and 16.6 \pm 5.7 , respectively). PNV and the mean aggregation index of natural vegetation (AI-NV) showed significant positive correlation in five of the six subregions:
The strongest relationship occurred at the Llanuras Occidentales region (LL-OCC, $R^{2}=0.93$ ). LL-VER was the only region in which such a relationship was not significant $\left(R^{2}=0.18\right)$.

The common trend in the relationships between parcel size with PNV and AI-NV consisted of a rapid increase in both (PNV and AI-NV) from the small parcel size until reaching a maximum, then steadily fluctuating at the largest parcels (see Fig. 5). Relative stability in PNV values seems to be reached at different parcel size intervals: 501-1000 ha (LLOCC and S-TAM), 2001-3000 ha (GSP) and 30014000 ha (LL-TAM).

The fastest rate of increase in PNV values as a function of larger parcel size occurred in the smallest parcel size intervals across five of the six subregions. Such a rapid increase happened in the 0-150 ha interval at the Sierra de Tamaulipas (STAM, 49\%), LL-OCC (46\%), and GSP (37\%), whereas LL-TAM and KH both showed a lower rate of $15 \%$. The PNV's rate of change significantly slowed down in the 151-1000 ha interval (Fig. 5), i.e., LL-VER, the only region in which PNV values remained fairly constant across parcel size intervals, up to $>1000$ ha (Fig. 5f).

Although there was a direct relationship between parcel size and PNV, the largest parcels did not uniformly have the highest PNV values. For example, in LL-VER, >10,000 ha parcels had a notably lower PNV (6\%) as compared to the 750010,000 ha interval $(52 \%)$. LL-TAM, the largest parcels, which included only one $>10,000$ ha parcel (NCP), had a lower PNV value (45\%) than the previous largest interval $(64 \%)$. On the other hand, in LL-OCC, six $>10,000$ ha parcels (3 EJ, 2 COL, and $1 \mathrm{TN}$ ) showed a PNV value (85\%), similar to the previous five largest intervals (82-88\%), making this region the only one in which PNV reached a maximum and stabilized in the largest parcels.

\section{Biodiversity patterns and land ownership types}

\section{Bird distributions}

The proportion of bird richness areas included in the different LOTs within each of the three subregions, i.e., Costa del Golfo, Llanuras Occidentales, and Sierras, for the most part showed frequency distributions decreasing as richness 
Fig. 4. Percentages of natural vegetation and mean aggregation index corresponding to communitybased and private land ownership types at three physiographic provinces (Costa del Golfo, Llanuras, and Sierras). Mean values are shown by the diamond dots while dash lines represent minimum and maximum values.

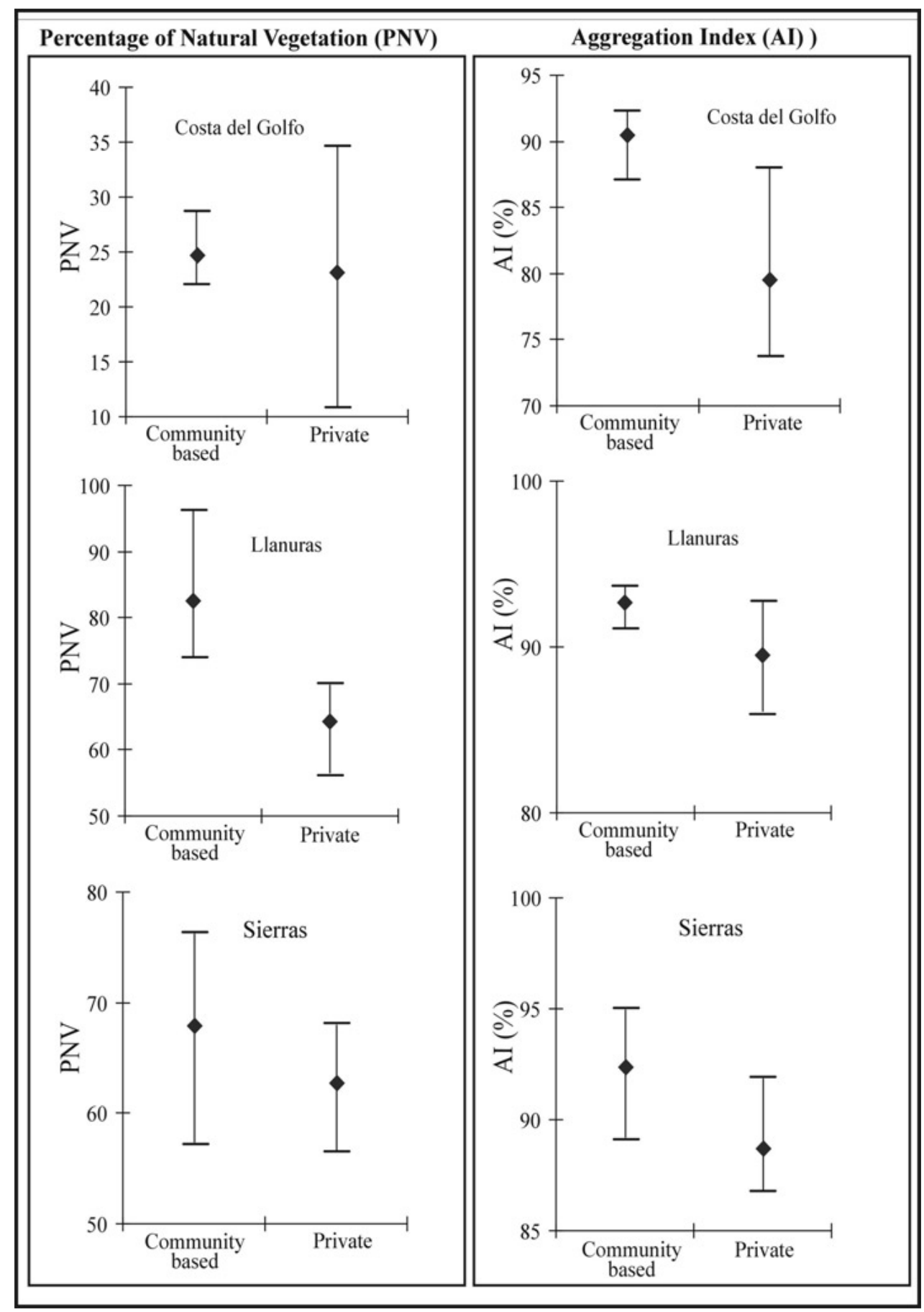


Fig. 5. Aggregation Index (AI, diamond symbol) and percentage of natural vegetation (PNV, bars) by parcel size, in six subregions; a) Gran Sierra Plegada, b) Llanuras Occidentales, c) Tamaulipas Plains and Hills, d) Karst Huasteco, e) Sierra de Tamaulipas, and f) Veracruz Plains and Hill. Parcel size intervals (x-axis) are shown at the bottom.

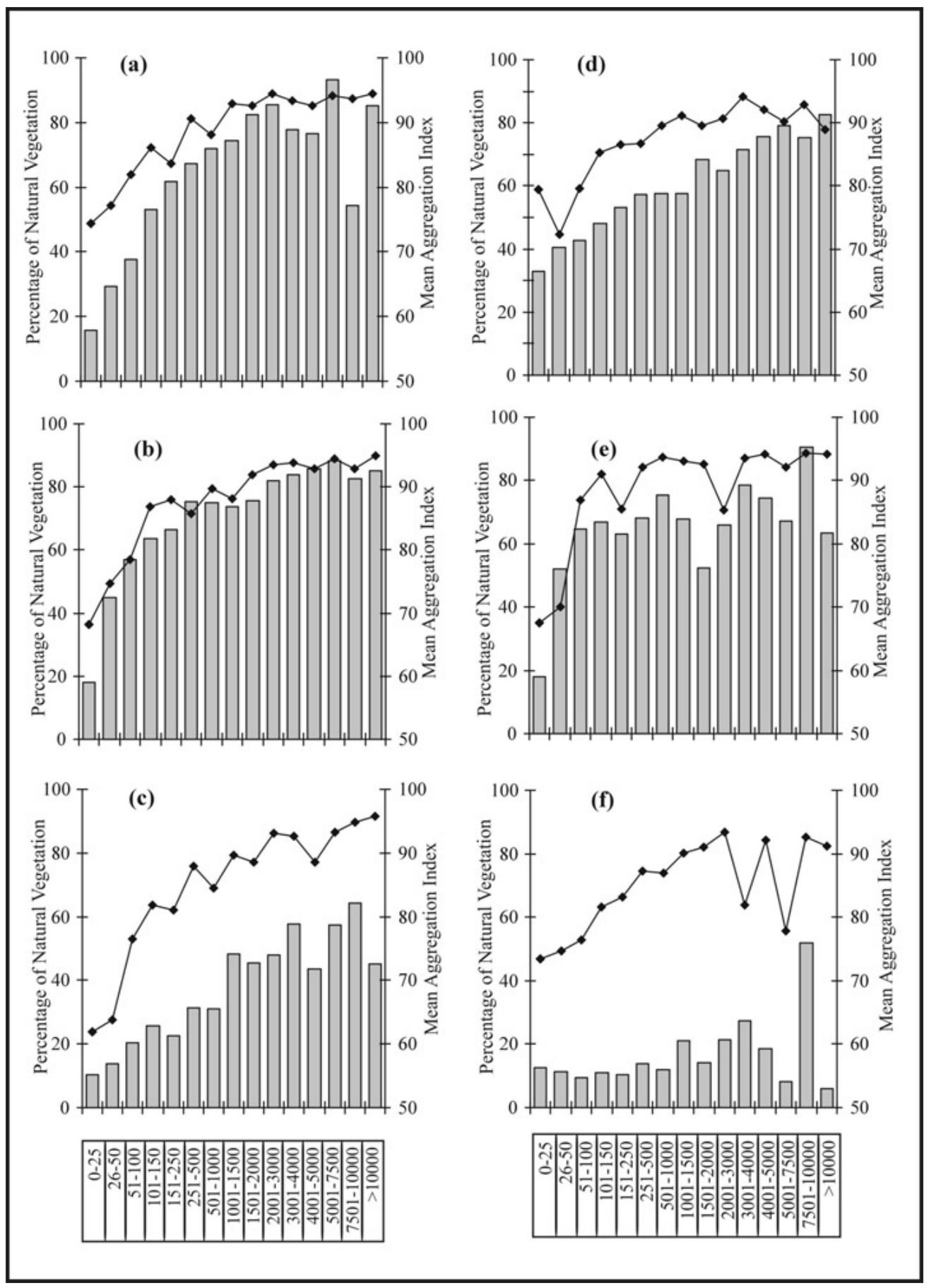


increased (Fig. 6). The percentages of areas for each richness interval represent the proportion of area in which a particular number of species occurs, in relation to each LOT's total area.

Costa del Golfo ( Fig. 6a): COM had the highest percentage of area with the highest bird richness (3\% for 101-125 spp.). COM maintained its dominance in the second richest interval (19\% for 76-100 spp), followed by TN (7\%). LOTs containing large proportional areas with the poorest richness (0-25 spp) included; PEQ (93\%), ZF (77\%), EJ (70\%), and PP (62\%).

Llanuras Occidentales (Fig 6b): EJ and TN showed highest area percentages with highest richness (both 2\% for 46-60 spp.), followed by PP and COM each with $1 \%$. The second highest richness interval (31$45 \mathrm{spp}$.) was best proportionally represented in NCP (53\%), followed by COL (38\%). Lowest richness (0-15 spp.) was uniformly associated with high proportional areas: $\mathrm{ZF}(80 \%), \mathrm{PP}(71 \%), \mathrm{TN}(70 \%)$, COM (66\%), PP (57\%) and EJ (50\%).

Sierras: NCP (Fig. 6c) showed the highest area percentage (2\%) for the richest interval (101-125 spp). NCP also dominated the second highest richness interval (32\% for 76-100 spp.), followed by EJ and PP, both with $10 \%$. Areas of low current richness (0-25 spp.) were best proportionally represented in ZF (66\%) and COM (59\%).

\section{Mammal distribution}

For mammals, percentages of areas for current richness varied according to each subregion, similarly to birds.

Costa del Golfo (Fig.6d). Areas with $>25$ species showed higher proportional representation in COM (21\%). Other LOTs with high richness (>20 spp.) included TN $(27 \%)$ and COL (13\%). Low current richness (0-10 spp.) areas were highly represented in ZF (79\%), PEQ (68\%), and EJ (60\%).

Llanuras Occidentales (Fig. 6e): The richest areas (21-25 spp.) were more highly represented in COL, EJ, and PP, each with $\sim 1 \%$. The next highest richness interval (16-20\%) was best proportionally represented in NCP $(33 \%)$ and COL $(28 \%)$. ZF (83\%), PEQ (76\%), and COM $(74 \%)$ were LOTs with highest PA values corresponding to low richness (0-5 spp.).
Sierras (Fig. 6f): Areas of highest richness (>25 spp.) occurred at NCP (23\%), followed by EJ (7\%) and $\mathrm{COM}(3 \%)$. The second richest interval (21-25 spp.) was also dominated by NCP, with PP and EJ at $11 \%$. Low richness areas (0-10 spp.) were best represented in COM (73\%), PEQ, and ZF (both $64 \%)$, and PP (52\%).

\section{Species listed as endangered, threatened, or with a restricted distribution and land ownership types}

Concentrations of biodiversity were also estimated by calculating the proportion of the total areas occupied by bird and mammal species considered endangered, threatened, or restricted in their distribution (ETRD), within the different land ownership types (LOTs). Considering my objective for comparing private vs. community-based land tenure, the eight LOTs were grouped into three classes: (1) private: PP, PEQ, and COL, (2) community based: EJ, NCP, and COM, and (3) government owned: $\mathrm{ZF}$ and TN. Tables 4 and 5 show the results of the comparisons for birds and mammals, respectively.

Twelve ETRD bird species were similarly included (group A, Table 4): 33-50\% of their total area by both generic private and community based LOTs. For the rest of species, private LOT included $10 \%$ more area for eight species than community-based lands (group B, Table 4). On the other hand, there were as many as 14 species with a $10 \%$ higher proportion of area included in community-based LOTs, than private lands (group C, Table 4). It is apparent, however, that more habitat-specialized species (A. Townsend Peterson, personal communication) are better represented in community-based LOTs: Ara militaris, Aratinga holochlora, Campylopterus curvipennis, Crax rubra, Dendrortyx barbatus, Momotus coeruliceps, Parula nigrilora, Piculus aeruginosus, and Pionus senilis.

Five ETRD mammals, were $10 \%$ better represented on private lands than on community-based lands (group B, Table 5), whereas community-based LOTs included 10 species with a $10 \%$ higher distribution than the private LOT (group C, Table 5). Species with similar distributions in both LOTs (12-50\%) were Choeronycteris mexicana, Oryzomys palustris, and Ursus americanus (group A, Table 5). 
Fig. 6. Highest current bird and mammal species richness by land ownership type, in three subregions: Costa del Golfo, Llanuras, and Sierras. Land ownership types (x-axis) include ZF= federal lands, TN= Nation lands, $\mathrm{PP}=$ private property, $\mathrm{PEQ}=$ small private property, $\mathrm{COL}=$ colonia, a settlement for agriculture/cattle-raising, $\mathrm{EJ}=E j i d o, \mathrm{COM}=$ communal, and $\mathrm{NCP}=$ new population settlement (new Ejido). Y-axis represents the percentage of each land ownership type containing species richness, as shown in labels.

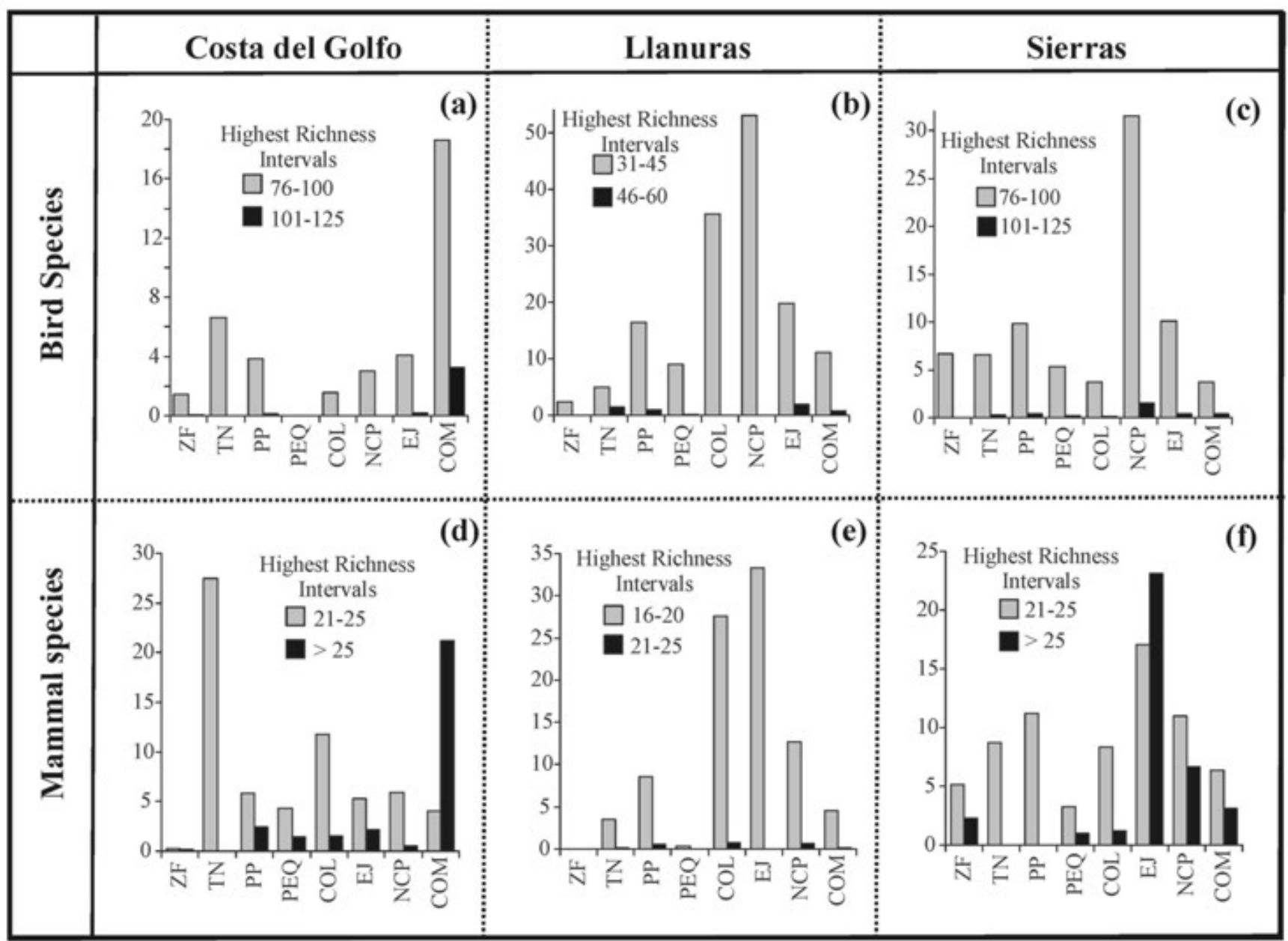

\section{DISCUSSION}

\section{Landscape patterns by land ownership type}

In general, the eight land ownership types included in this study correspond to those referred to in the literature as examples of the broad spectrum of land property regimes (e.g., GTZ 2002), which range across private, communal, and state property. Hence, this study incorporates an important diversity of ownership types. The specific social, economic, and cultural nature of each land tenure system is beyond the scope of this study. Therefore, this study is truly exploratory, focusing on the spatial landscape and biodiversity patterns associated with different land ownership regimes.

The different LOTs in each of the three subregions of the community-based lands EJ, NCP, and COM tended to show higher percentages and higher 
diversity of natural vegetation in comparison with that of private lands PP, PEQ, and COL. The greater diversity of LULC shown by the main LOTs, EJ, and PP, appeared to be related to their dominance of areas, e.g., $78 \%$ of the total area at the Costa del Golfo. Nevertheless, COM had the highest evenness in LULC areas, whereas PP and EJ were dominant in agricultural and introduced grassland areas. Similarly, even though EJ and PP were also dominant in LOTs at Llanuras Occidentales, COM showed the greater diversity of original vegetation types and the greater evenness of LULC.

Low evenness values represent dominance of one or a few original vegetation types or human-induced LULC. For instance, NCP had very low MSIEI values at the Llanuras Occidentales and Sierras, which reflects dominance of shrub land and tropical dry forest, respectively. On the other hand, PP at the Costa del Golfo subregion, showed the lowest evenness of LULC areas because of a $76 \%$ dominance of agriculture and introduced grassland, whereas ZF lands at the Sierras also had low evenness, which reflected a $74 \%$ dominance on transformed lands.

The use of the aggregation index (AI) in this study was intended to provide information about differences in the spatial patterns of original vegetation among LOTs and among parcels of varying sizes. The direct relationship between PNV and AI-NV would seem obvious considering that a higher PNV represents large and continuous areas with higher spatial aggregation rather than smaller areas. Therefore, the dominant LOTs, e.g., PP and EJ, would be expected to show the highest AI-NV values. However, because of the AI's proportional makeup, the highest AI-NV values across the three subregions were shown by other LOTs with much smaller areas such as TN, COM, NCP, and COL. In fact, the community-based LOTs showed slightly higher mean values in the aggregation of natural vegetation, than did the private types: $90.4 \pm 0.6 \mathrm{vs}$. $79.5 \pm 1.6$ at Costa del Golfo; $92.7 \pm 0.3$ vs. $89.5 \pm 0.7$ at the Llanuras Occidentales; and $92.4 \pm 0.6$ vs. 88.7 \pm 0.6 at the Sierras. Although the AI allows reasonable comparisons of landscapes in their levels of aggregation (Hong at al. 2000), my results should be taken with caution because of the global nature in the calculations.

\section{Landscape patterns by parcel type}

Results related to the percentage of natural vegetation by parcel size interval revealed that most of the original vegetation has been removed from the Gulf of Mexico coastal plains and hills (LL-VER and LL-TAM). There is a direct relationship between parcel sizes and both the percentage and aggregation of the remaining original vegetation. In other words, land availability appears to be an important factor in the conservation of areas of natural vegetation for landholders of small- and medium-size parcels, but not for owners of larger parcels. Although there was some variation among physiographic provinces, small- and medium-size parcels (e.g., 0-500 ha) showed greater rates of increase of PNV as a function of size than did larger parcels. The 500-1000 ha extent seems to be a threshold at which land availability does not play the same role in determining the amount of natural vegetation conserved by landowners.

Environmental conditions also contribute to land availability, as indicated by the lowest mean PNV across size interval in the plains and hills of the Gulf of Mexico (33\% for LL-TAM and 14\% for LLVER), as compared to the other subregions, which had $60-70 \%$ mean PNV across size intervals. This seems to be a function of mountain topography (GSP, KH, S-TAM) and a scarcity of resources, e. g., water in LL-OCC and soils at the sierras. Nevertheless, the higher percentages of natural vegetation correspond to thresholds of original habitats occurring as patch mosaics of transformed environments (Jaeger 2000), which is also an indication of the deforestation processes that occur across the region.

Finally, particular management practices are also reflected in variations in PNV and AI across size intervals. An excellent example is the case of an irrigation district with large parcels and large AI, but with drastically reduced PNV. Similarly, an NCP had >10,000 ha in S-TAM, highly deforested for raising cattle; its PNV was thus much lower than the previous size interval.

\section{Biodiversity patterns by land ownership type}

Reflecting the relatively lower landscape transformation, community-based land ownership better proportionally represented the richest areas of bird and mammal species. This trend follows the 
nationwide phenomenon that communal-indigenous lands show higher diversity (Gómez-Pompa 1998). Merging LOTs in three groups, comparisons revealed that community-based ownership included higher percentages of the total distributional areas of more bird and mammal species considered threatened, endangered, or with restricted distributions (ETRD), than did private or government lands. Even though TN had highest PNV in the three subregions, only one ETRD bird species was best represented in TN. Communitybased ownership not only included more ETRD bird species, but also comprised species that were much more highly habitat specialized.

The general trends identified in this study point toward the community-based LOTs as presenting heterogeneous conditions and housing the highest biodiversity indicators. Nevertheless, these land tenure systems show a variety of conditions, ranging from highly deforested to highly dominated by natural vegetation cover. On the other hand, the biodiversity estimates presented in this study are based on models that necessarily convey some level of uncertainty, such as the heuristic nature of the species distribution models, along with the uncertainty derived from using a small sample size for the number of sites for some species.

Considering that no land tenure system by itself is the recipe for ecological sustainable resource management (Alcorn 1991, Alcorn and Toledo 1998), this study highlights the importance of community-based land ownership for containing high levels of biodiversity and suitable habitats for wildlife. The differences in landscape patterns and biodiversity indicators among land ownership regimes found in this study, are ultimately the result of land tenure systems defining the relationship between people and land's natural resources, throughout determining rights and obligations for access and exclusion (Grover et al. 2006). Research into the relationship land tenure and biodiversity, concerning property rights and issues of control, access, and use of land, has been scarce (Mackenzie 2003). Our study contributes in analyzing whether private, public, or communal land ownership promotes sustainable management of natural resources (Walters et al. 2006, Baland and Platteau 1996, Ostrom 1990). However, the concurrence of different land ownership types within our study region necessarily requires analysis of the broader socioeconomic and political contexts in which biodiversity conservation takes place (Goeschl and Igliori 2006).

A key aspect of the land tenure-biodiversity relationship relates to a distinctive attribute of community-based or indigenous lands, i.e., the ecological knowledge of local people who manage and conserve natural resources. This has been increasingly recognized by international laws and forums such as the Convention on Biological Diversity (Mauro and Hardison 2000). The applications of traditional knowledge for developing alternative systems of sustainable production have been broadly documented in Mexico (Toledo et al. 2003) and elsewhere (Alcorn 1983,1987, Posey 1985, Gómez-Pompa 1987, Denevan and Padoch 1988, Gómez-Pompa and Kaus 1990, Reed 1995).

Our results point out that community-based lands may contain higher percentages of areas with original vegetation. These results agree with studies on communal management of natural resources, including those by Bray et al. (2004) who demonstrated that common property lands in Mexico are examples of long-settled agricultural and forest extraction landscapes that have preserved significant forest cover. Because of the political, economic, and ecological conditions associated with the community-based models of land ownership and natural resources management, Mexico is a unique laboratory for analyzing relationships between land tenure regimes and strategies for biodiversity conservation (Bray et al. 2003).

Responses to this article can be read online at:

http://www.ecologyandsociety.org/vol12/iss2/art12/responses/

\section{Acknowledgments:}

This work was part of the first author's Ph.D. dissertation at the Department of Geography, University of Kansas. I thank the Consejo Nacional de Ciencia y Tecnología (CONACyT) for providing the scholarship that made possible this research. The database of bird collection records was provided by Adolfo Navarro Singuenza (Facultad de Ciencias, UNAM) and A. Townsend Peterson (Natural History Museum, University of Kansas). 
The database of mammals was provided by CONABIO, Héctor Arita (Instituto de Ecología, UNAM) and Victor Sánchez-Cordero (Instituto de Biología, UNAM). Finally, I thank the Universidad de Colima and Leslie Larson for their support.

\section{LITERATURE CITED}

Alcorn, J. B. 1983. El te'lom Huasteco: Presente, pasado y futuro de un sistema de silvicultura indígena. Biotica 89(30):315-331.

Alcorn, J. B. 1987. Indigenous agroforestry systems in the Latin American tropics. Pages 203-218 in Amiguel A. Altieri and Susanna B. Hecht, editors. Agroecology and Small Farm Development CRC Press, Boca Raton, Florida, USA.

Alcorn, J. B. 1991. Ethics, economies, and conservation. Pages 317-349 in M. L. Oldfield and J. B. Alcorn, editors. Biodiversity: culture, conservation and ecodevelopmentWestview Press, Boulder, Colorado, USA.

Alcorn, J. B., and V. M. Toledo. 1998. Resilient resource management in Mexico's forest ecosystems: the contribution of property rights. Pages 216-249 in F. Berkes, C. Folke, and J. Colding, editors. Linking social and ecological systems, management practices and social mechanisms for building resilience. Cambridge University Press, Cambridge, UK.

Altieri, M. A. 1993. Traditional farming in Latin America. The Ecologist 21(2):93-96.

Anderson, R. P., D. Lew, and A. T. Peterson. 2003. Evaluating predictive models of species' distributions: criteria for selecting optimal models. Ecological Modelling 162:211-232.

Baland, J., and J.-Ph. Platteau. 1996. Halting degradation of natural resources: is there a role for rural communities? Clarendon, Oxford, UK.

Barton-Bray, D. 1996. Of land tenure, forest, and water: the impact of the reforms to article 27 on the Mexican environment. Pages 215-221 in Laura Randall, editor. Reforming Mexico's Agrarian reform. M. E. Sharpe, New York, New York, USA.
Barton-Bray, D., L. Merino-Pérez, P. NegrerosCastillo, G. Segura-Warnholtz, J. M. TorresRojo, and H. F. M. Vester. 2003. Mexico's community-managed forests as a global model for sudtainable landscapes. Conservation Biology 17 (3):672-677.

Bartra, R. 1993. Agrarian dtructure and political power in Mexico. The John Hopkins University Press, Baltimore, Maryland, USA.

Beaumont, P. M., and R. T. Walker. 1996. Land degradation and property regimes. Ecological Economics 18:55-66.

Bray, D. B., L. Merino-Pérez, P. NegrerosCastillo, G. Segura-Warnholtz, J. M. TorresRojo. 2003. Mexico's community-managed forests as a global model for sustainable landscapes. Conservation Biology 17(3):672-677.

Bray, D. B., E. A. Ellis, N. Armijo-Canto, and C. T. Beck. 2004. The institutional drivers of sustainable landscapes: a case study of the 'Mayan Zone' in Quintana Roo, Mexico. Land Use Policy 21:333-346.

Brush, S. B. 1984. Genetic diversity and conservation in traditional farming systems. Journal of Ethnobiology 6(1):151-167.

Brunt, D. 1992. Mastering the struggle, gender actors and agrarian change in a Mexican Ejido. CEDLA, Amsterdam, The Netherlands.

Comisión Nacional para el Estudio y Conservación de la Biodiversidad (CONABIO). 2003. Digital spatial data available at: http://conabi oweb.conabio.gob.mx/metacarto/metadatos.pl.

Cornelius, W. A., and D. Myhre. 1998. The transformation of rural Mexico, reforming the Ejido. Center of United States-Mexico Studies at the University of California, San Diego, La Jolla, California, USA.

Crow, T., G. E. Host, and D. J. Mladenoff. 1999. Ownership and ecosystem as sources of spatial heterogeneity in a forested landscape. Landscape Ecology 14:449-463.

De Gortari, L. 2002. Comunidad como forma de tenencia de la tierra. Available online at: http://ww w.pa.gob.mx/publica/pa070806.htm. 
DeWalt, B. R. 1998. The Ejido reforms and Mexican Coastal Communities: fomenting a blue revolution. Pages 357-379 in Wayne A. Cornelius and David Myhre, editors. The transformation of rural Mexico, reforming the Ejido. Center of United States-Mexico Studies at the University of California, San Diego, La Jolla, California, USA.

Denevan, W. M. 1980. Latin America. In Gary A. Klee, editor. World Systems of Traditional Resource Management. John Wiley and Sons, New York, New York, USA.

Denevan, W. M., J. M. Treacy, J. B. Alcorn, C. Padoch, J. Denslow, and S. Flores-Paitan. 1984. Indigenous agroforestry in the Peruvian Amazon: Bora Indian management of swidden fallows. Interciencia 9(6):346-357.

Denevan, W. M., and C. Padoch. 1988. Swiddenfallow agroforestry in the Peruvian Amazon. Advances in Economic Botany 5 New York Botanical Garden, New York, New York, USA.

Feeny, D. F. Berkes, B. J. McCay, and J. M. Acheson. 1990. The tragedy of the commons: twenty-two years later. Human Ecology 18(1):1-19.

Geisler, C., and S. Salamon. 1993. Returning land tenure to the forefront of rural sociology. Rural Sociology 58(4):529-531.

Gesellschaft für Technische Zusammenarbeit (GTZ). 2002. Guiding principles: land tenure in development cooperation. Available online at: http ://www.mekonginfo.org $/ \mathrm{mrc} / \mathrm{html} /$ tenure $/ \mathrm{te}$ frm.htm

Gilbert, J., and C. K. Harris. 1984. Changes in type, tenure, and concentration of U. S. farmland owners. Rural Sociology and Development 1:135-160.

Gliessman, S. R. 1992. Agroecology in the tropics: achieving a balance between land use and preservation. Environmental Management $\mathbf{1 6}$ (6):681-689.

Goeschl, T., and D. C. Igliori. 2006. Property rights for biodiversity conservation and development: extractive reserves in the Brazilian Amazon. Development and Change 37(2):427-451.
Gómez-Pompa, A. 1987. Tropical deforestation and Maya silviculture: an ecological paradox. Tulane Studies in Zoology and Botany 26(1):19-37.

Gómez-Pompa, A. 1999. Conservación de la biodiversidad en México: Mitos y Realidades. Boletín de la Sociedad Botánica de México 63:33-41.

Gómez -Pompa, A., and A. Kaus. 1990. Traditional management of tropical forests in Mexico. Pages 45-64 in A. B. Anderson, editor. Alternatives to deforestation, steps toward the sustainable use of the Amazon Rain Forest. Columbia, University Press, New York, New York, USA.

Grover, R., M. P. Torhonen, and D. Pamer. 2006. The importance of land tenure data in decision making: land reform, land settlement and cooperatives 2006/1. FAO. Available online at: htt p://www.fao.org/sd/LTdirect/landrf.htm.

Hardin, G. 1968. The tragedy of the commons. Science 162: 1243-1248.

Hong S. He., E. B. DeZonia, and D. J. Mladenoff. 2000. An aggregation index (AI) to quatify spatial patterns of landscapes. Landscape Ecology 15:591-601.

Jaeger, J. A. G. 2000. Landscape division, splitting index, and effective mesh size: new measures of landscape fragmentation. Landscape Ecology 15:115-130.

Klee, G. A. 1996. Traditional concepts for 21st century living. Etnoecológica, 3(4/5), Available online at: http://www.etnoecologica.org.mx.

Ley Agraria 1992. Diario Oficial de la Federación del 26 de Febrero de 1992. Secretaría de la Reforma Agraria, Mexico D.F.

Lovett-Doust, J., and K. Kuntz. 2001. Land ownership and other landscape-level effects on biodiversity in southern Ontario's Niagara Escarpment Biosphere Reserve, Canada. Landscape Ecology 16:743-755.

Lovett-Doust, J., M. Biernacki, R. Page, M. Chan, R. Natgunarajah, and G. Timis. 2003. Effects of land ownership and landscape-level 
factors on rare species richness in natural areas of southern Ontario, Canada. Landscape Ecology 18:621-633.

Mauro, F., and P. D. Hardison. 2000. Traditional knowledge of indigenous and local communities: International debate and policy initiatives. Ecological Applications 10(5):1263-1269.

McCabe, T. J. 1990. Turkana pastoralism: a case against the tragedy of the commons. Human Ecology 18(1):81-103.

McGarigal, K., S. A. Cushman, M. C. Neel, and E. Ene. 2002. FRAGSTATS: spatial pattern analysis program for categorical maps. Computer software program produced by the authors at the University of Massachusetts, Amherst. Available online at: http://www.umass.edu/landeco/research/ fragstats/fragstats.html.

Matzke, G. E., and N. Nabane. 1996. Outcomes of a vommunity vontrolled eildlife utilization program in a Zambezi Valley community. Human Ecology 24(1):65-85.

Mackenzie, A. F. D. 2003. Land tenure and biodiversity: an exploration in the political ecology of Murang's District, Kenya. Human Organization 62(3):255-266.

Merino, L. 2004. Conservación o deterioro. El impacto de las políticas públicas en las instituciones comunitarias y en el uso de los bosques en México. Secretaria del Medio Ambiente y Recursos Naturales, Instituto Nacional de Ecología, Consejo Civil Mexicano para la Silvicultura Sostenible A. C.

Ortega-Huerta, M. A., and T. A. Peterson. 2004. Modelling spatial patterns of biodiversity for conservation prioritization in northeastern Mexico. Diversity and Distributions 10:39-54.

Ortega-Huerta, M. A. In press. Fragmentation patterns and implications for biodiversity conservation in three biosphere reserves and surrounding regional environments, northeastern Mexico. Biological Conservation 134:83-95.

Ostrom, E. 1990. Governing the commons: the evolution of institutions for collective zction. Cambridge University Press, Cambridge, UK.

Ostrom, E. 1992. The rudiments of a theory of the origins, survival, and performance of commonproperty institutions Pages 293-318 in D. Bromley, editor. Making the commons work: theory, practice, and policy. Institute for Contemporary Studies, San Francisco. California, USA.

Peterson, A.T. 2001. Predicting species geographic distributions based on ecological niche modeling. Condor 103:599-605.

Posey, D. A. 1985. Indigenous management of tropical forest ecosystems. The case of the Kayapó Indians of the Brazilian Amazon. Agroforestry Systems 3:139-158.

Reed, R. K. 1995. Prophets of agroforestry: Guarani communities and commercial gathering. University of Texas Press, Austin, Texas, USA.

Rose, C. 2002. Common property, regulatory property, and environmental protection: comparing community-based management to tradable environmental allowances. Pages 233-257 in E. Ostrom, T. Dietz, N. Dolsak, P. C. Stern, S. Stonich, and E. U. Weber, editors. The dranma of the commons. National Academy Press, Washington, D.C., USA.

Secretaróa de la Reforma Agraria (SRA). 1993. Reglamento de la Ley Agraria en materia de ordenamiento de la propiedad rural. Diario Oficial de la Federación, Jueves 4 de Enero de 1993.

SEMARNAT. 2001. Vegetación y uso de suelo 2000 Inventario Forestal. Secretaría de Medio Ambiente y Recursos Naturales, Universidad Nacional Autónoma de México (Instituto de Geografía), y Instituto Nacional de Estadística Geografía e Informática, editors. México D. F.

Snyder, R. 1998. The changing role of Ejido. Pages 1-6 in R. Snyder and G. Torres, editors. The future role of the Ejido in rural Mexico. Center for United States-Mexico Studies at The University of California, San Diego, La Jolla, California, USA.

Stockwell, D. and D. Peters. 1999. The GARP modelling system: problems and solutions to automated spatial prediction. International Journal of Geographical ormation Science 13(2):143-158.

Stockwell, D. R. B. and A. T. Peterson. $2002 a$. Controlling bias in biodiversity data. Predicting species occurrences: issues of scale and accuracy. Pages 537-546 in J. M. Scott, P. J. Heglund, and M. 
L. Morrison, editors. Island Press, Washington, D. C., USA.

Stockwell, D. R. B. and A. T. Peterson. $2002 b$. Effects of sample size on accuracy of species distribution models. Ecological Modelling 148:1-13.

Toledo, V. M. 1987. Vacas, cerdos, pollos, y ecosistemas, ecología y ganadería en México. Ecología 3:36-49.

Toledo, V. M. 1992. La racionalidad ecológica de la producción campesina. Pages 197-218 in E. Sevilla-Guzmán and M. González de Molina, editors. Ecología, Campesinado e Historia. La Piqueta, Madrid, Spain.

Toledo, V. M. 1996. The ecological consequences of the 1992 Agrarian law of Mexico. Pages 247-263 in Laura Randall, editor. Reforming Mexico's Agrarian reform. M. E. Sharpe, New York, New York, USA.

Toledo, V. M., B. Ortiz-Espejel, L. Cortés, P. Moguel, and M. Ordoñez. 2003. The multiple use of tropical forests by indigenous peoples in Mexico: a case of adaptive management. Conservation Ecology 7(3):9. [online] URL: http://www.consecol. org/vol7/iss3/art9/.

Warman, A. 1984. Notas para una redefinición de la comunidad agraria. Revista Mexicana de Sociología (Julio-septiembre) 3:11.

Wexler, M. B., and D. Barton-Bray. 1996. Reforming forests: from community forests to corporate forestry in Mexico. Pages 235-245 in Laura Randall, editor. Reforming Mexico's Agrarian reform. M. E. Sharpe, New York, New York, USA.

Whiteford, S., and F. A. Bernal. 1996. Campesinos, water, and the state: different views of La Transferencia. Pages 223-234 in Laura Randall, editor. Reforming Mexico's Agrarian reform. M. E. Sharpe, New York, New York, USA.

Whiteford, S., F. A. Bernal, H. Diaz-Cisneros, and E. Valtierra-Pacheco. 1998. Arid-land Ejidos: bound by the past, marginalized by the future. Pages 381-399 in W. A. Cornelius and D. Myhre, editors. The transformation of rural Mexico, reforming the Ejido. Center of United States-Mexico Studies at the University of California, San Diego, La Jolla, California, USA.

Wilken, G. C. 1989. Transferring traditional technology: a bottom-up approach for fragile lands. Pages 44-60 in John O. Browder, editor. Fragile lands of Latin America, strategies for sustainable development. Westview, Boulder, Colorado, USA.

Wunderlich, G., and W. E. Chryst. 1958. Farm tenure and use of land. Pages 295-301 in Yearbook of agriculture. United States Department of Agriculture. Washington, D.C., USA.

Young, O. R. 2000. Institutional interplay: the environmental consequences of cross-scale interactions. Presented at Constituting the Commons: Crafting Sustainable Commons in the New Millenium, the Eighth Conference of the International Association for the Study of Common Property (May 31-June 4), Bloomington, Indiana, USA.

Zabin, C. 1998. Free markets and forests: community-based forestry in the eraa of neoliberal reform. Pages 401-425 in Wayne A. Cornelius and David Myhre, editors. The transformation of rural Mexico, reforming the Ejido. Center of United States-Mexico Studies at the University of California, San Diego, La Jolla, California, USA.

Walters, D. J. J., D. C. Kotze, and T. G. O'Connor. 2006. Impact of land use on vegetation composition, diversity, ans selected soil properties of wetlands in the southern Drakensberg mountains, South Africa. Wetlands Ecology and Management 14:329-348. 
APPENDIX 1. Equation 1: Aggregation Index (AI).

$$
A I=\left[\frac{g_{i i}}{\max \rightarrow g_{i i}}\right](100)
$$

Where:

$\mathrm{g}_{\mathrm{i}}=$ Number of like adjancies (joins) between pixels of patch type (class) $\mathrm{i}$ based on the single count method.

Max-- $>\mathrm{g}_{\mathrm{ii}}=$ Maximum number of like adjancies (joins) between pixels of patch type (class) i based on the single-count method. 
APPENDIX 2. Equation 2: Shannon's Diversity Index (SHDI).

$$
\text { SHDI }=-\sum_{i=1}^{m} P_{i}^{*} \operatorname{Ln} P_{i}
$$

\section{Where: \\ $\mathrm{P}_{\mathrm{i}}=$ Proportion of the landscape occupied by patch type (class) $\mathrm{i}$.}


APPENDIX 3. Equation 3: Modified Simpson's Evenness Index (MSIEI)

$$
M S I E I=\frac{-\ln \sum_{i=1} P_{i}^{2}}{\ln m}
$$

Where:

$\mathrm{P}_{\mathrm{i}}=$ Proportion of the landscape occupied by patch type.

$\mathrm{m}=$ number of patch types (classes) present in the landscape, excluding the landscape border if present 